\title{
Identification of Endophytic Bacterial Isolated from Oil Palm Plants with Anti-Fungal Acitvity against Ganoderma boninense
}

Irma Mardiah

School of Life Science and Technology, Bandung Institute of Technology,

Bandung, West Java, Indonesia

\begin{abstract}
Endophytic bacteria is an excellent candidates for the biological control of pathogenic fungi in plantations. The objectives of this study were to isolate and examine anti-fungal activity of endophytic bacteria from oil palm plantations in South Kalimantan against Ganoderma boninense. This research was performed in three phases, i.e., isolation, selection, and assessment of endophytic bacteria isolates against Ganoderma boninense. A total of 126 colonies of endophytic bacteria were isolated. The result of the anti-fungal activity test with dual culture method demostrated that BKA 10 isolate had the largest inhibition zone $(62.22 \%)$. Molecular identification by DNA analysis using 16S rRNA primers showed that BKA 10 is most closely related to Bacillus cereus. In conclusion, isolate with the best anti-fungal acitivity against Ganoderma boninense has the closest kinship with Bacillus cereus.
\end{abstract}

Keywords: antifungal, dual culture, Bacillus cereus.

\section{Introduction}

Indonesia is one of the country with the largest oil palm plantations in the world. ${ }^{1}$ In 2013, Indonesia's oil palm plantations reached 10.32 million hectares with palm oil production reached 31 million tons. ${ }^{2}$ Indonesia contributed to $46 \%$ of global palm oil exports, making Indonesia top the lists of palm-oil producing countries. ${ }^{3}$ Unfortunately, oil palm plantations in Indonesia currently face the deadly basal stem rot disease caused by Ganoderma spp. ${ }^{4}$ It has been reported that the economic loss caused by these pathogens in the region of Southeast Asia is more than 500 million dollars per year. ${ }^{5}$
Various control methods have been applied to overcome this disease, but nothing seems to be effective. For a long time, burning land to iron out this disease is common method, but this causes environmental damage in the region. The use of chemical fungicides such as hexaconazole is also rarely performed because besaid causing pollution, this method does not show effective results. ${ }^{6}$ To reduce the use of chemical agents and environmental pollution, several studies have shown the potential use of biocontrol agents that are more effective and more environmentalfriendly in controlling plant pathogens ${ }^{7}$.

Corresponding author: Irma Mardiah, School of Life Science and Technology, Bandung Institute of Technology, Bandung, West Java, Indonesia. Email: imardiah2@gmail.com

Received: 06 July 2018. Revised: 28 July 2018. Published: 31 August 2018. 
The observation of the low incidence of diseases caused by Ganoderma sp. species pathogenic fungi in a number of plantations suggested that the disease was likely to be controlled by a biocontrol agent. Therefore, many research has been conducted to control Ganoderma sp. with the use of biocontrol agents. ${ }^{8}$ The study conducted by Idris shows that endophytic fungi can be used to compete against Ganoderma sp. ${ }^{9}$ thus reducing the chances of Ganoderma $s p$. to colonize the roots of oil palm plantations. Beside that, a promising biocontrol agent such as Trichoderma $s p$ demonstrated in-vitro antagonism activity against $G$. boninense. ${ }^{10}$

Endophytic bacterial are the bacteria that live in plant tissues without any symptoms of the disease shown by the host. ${ }^{11,12}$ Several endophytic bacteria indicate the presence of antagonistic properties against pathogenic fungi that attack host. ${ }^{13,14}$ They have been isolated from wild hosts as well as those grown in agriculture and plantations, such as woody plants, ${ }^{15}$ bananas, ${ }^{16}$ and grasses. ${ }^{17}$ Thus, endophytic bacterial is a relatively new candidates for biological disease control.

A large number of endophytic bacteria, including gram-positive and negative could help their host against pathogens through lysis activity of fungal cell wall. ${ }^{7}$ Several endophytic bacteria such as Serratia spp., Burkholderia spp., Pseudomonas spp., Bacillus spp., And Fusarium spp., which were found to induce a crop resistance system showed antibiotic and lysis activity ${ }^{13,14}$.

Therefore, this study was conducted to identify selected endophytic bacteria that have anti-fungal properties against Ganoderma boninense. This endophytic bacteria was isolated from oil palm plantations from the Agro plantation of Menara Rahmat in South Kalimantan. Data from this study are useful for further studies regarding selected antagonist endophytic isolates and other secondary metabolites against fungal pathogen.

\section{Methods}

Material

The materials used in this research are palm oil tissues (roots, stems, leaves and fruit) from PT. Agro Menara Rahmat, South Kalimantan and fungi culture of $G$. boninense from Laboratory of Mycology-PAU, School of Life Sciences and Technology, Bandung Institute of Technology.

\section{Sampling and isolation endophytic bacteria} Sampling of parts of oil palm plantation was conducted at PT Agro Menara Rahmat, South Kalimantan. Sampling of healthy plant oil palm parts (roots, stems, leaf barks, leaves and fruits) from several ages of oil palm crops was conducted randomly. Isolation of endophytic bacteria from oil palm plants was conducted by taking the tissues in the roots, stems, leaves and fruit aseptically. Each tissue (root, stem, leaves, and fruit) was sterilized using $70 \%$ ethanol and 2\% sodium hypochlorite, then planted in aseptic Nutrient Agar (NA) medium. After 48 hours incubation, bacterial isolates grown on the media was purified into pure culture and stored in a reaction tube containing NA media as a stock culture. $G$. boninense fungal pathogen culture is grown by taking tissue in the pathogen aseptically and growing it on the surface of Potato Dextrose agar (PDA) medium.

\section{Anti-fungal acitivity test}

$G$. boninense culture was placed in the middle of a Petri dish containing PDA medium (diameter: $8 \mathrm{~mm}$ ). Two days after the inoculation of the fungus, bacterial culture was streaked $(2 \mathrm{~cm})$ from the ends of the corners of the mycelium growth region. The inhibition zone was calculated when the mycelium reaches the tip of petri dish on control culture. 
Inhibiton zone resulting from dual culture results was calculated based on the formula. ${ }^{18}$

$$
Z H=\frac{R M K-R M H}{R M K} \times 100 \%
$$

Keterangan:

ZH : Inhibition Zone (\%)

RMK : Control Mycelium Radius (cm)

$\mathrm{RMH}$ : Inhibitory Mycelium Radius (cm)

\section{Identification of selected bacterial isolates}

Bacterial isolates were prepared for morphological observation of colonies, forms and types of bacterial cells with gram staining. The morphology of the colony was observed visually in petri dishes for the shape, color, edges, surface and colony growth patterns. Microscopic observations of bacterial cells were performed to look at the cell shape and reaction of the Gram. The gram staining technique was carried out in the following manner: the isolate smear was dropped with the basic dye of violet crystals and left for 1 minute, then washed with water flowing carefully. The smear was then stained with Gram Iodine (1 g Iodine composition, 2 $\mathrm{g}$ of potassium iodide) in $300 \mathrm{~mL}$ of distilled water and allowed to stand for 1 minute. The excess reagents were removed and the smear was soaked in $96 \%$ alcohol for 30 seconds. The swabs were washed with flowing water carefully. The smear was stained with $2.5 \%$ of safranin for 1 minute, washed again with flowing water carefully and then dried. Smear was observed with a microscope.

Amplification of 16S rRNA gene was done by PCR colony method. The pure bacterial isolates were grown on a solid NA medium and sampled one colony using Oose into 100 $\mu \mathrm{L}$ sterile deionized water and homogenized to be a template in the PCR process. Template of bacterial suspension was used as much as 2 $\mu \mathrm{L}$ and mixed with 16S rRNA forward primer $2.5 \mu \mathrm{L}\left(5^{\circ}\right.$-AGAGTTTGATCCTGGCTCAG3'), reverse $16 \mathrm{~S}$ rRNA $2.5 \mu \mathrm{L}$ (5 'GGTTACCTTGTTACGACTT - 3'), sterile water deion $14 \mu \mathrm{L}$, DMSO $4 \mu \mathrm{L}$, and PCR mix (Fermentas) $25 \mu \mathrm{L}$ in PCR tube. The PCR tube containing $50 \mu \mathrm{L}$ of mixed material was then homogenized using a vortex prior to PCR. PCR takes as many as 25 cycles.

DNA extraction from agarose gel was conducted using DNA purification kit from Geneaid. DNA sequencing was conducted

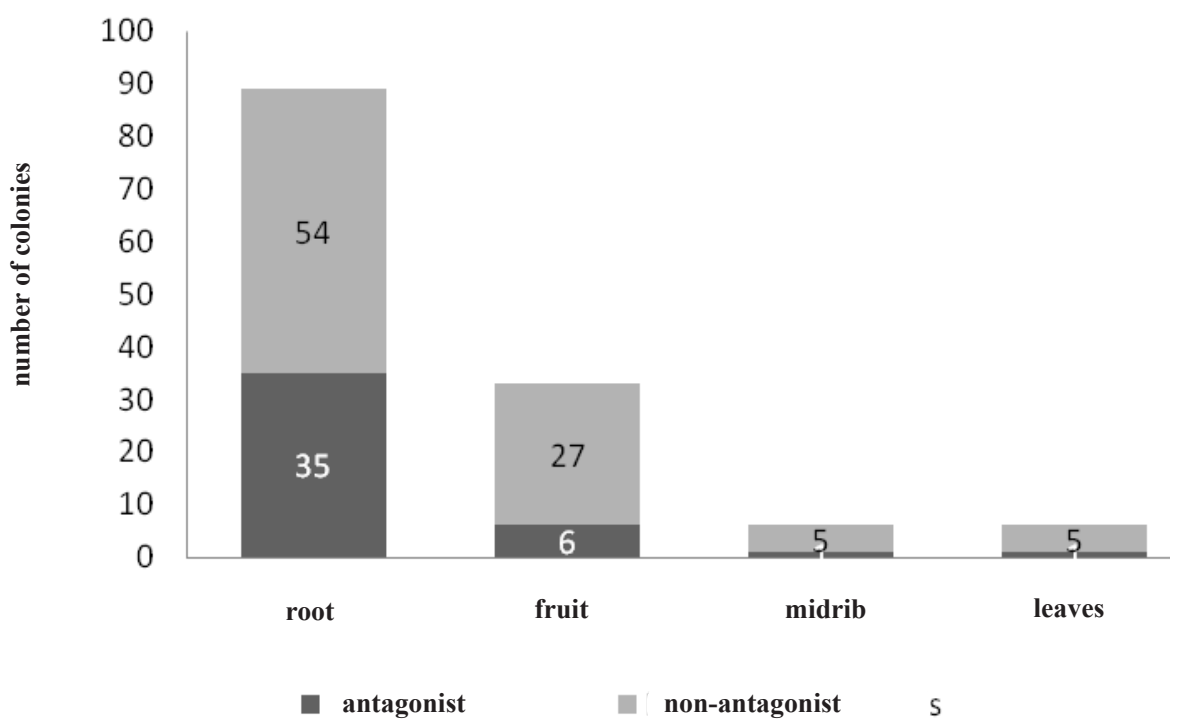

Figure 1. Comparison of Antagonistic \& Non-antagonistic Isolates from Palm Oil Explants 
at Macrogen Inc., Seoul South Korea. This sequence analysis was used as a basis for constructing phylogenetic trees.

The result of sequencing was edited using Bioedit program and then searched for reference species using BLAST nucleotide (BLASTn) search engine on NCBI website. The sequence of isolates was aligned with some reference species using the
CLUSTAL_W program version 2.0.11. The aligned sequence results were re-edited to remove unreadable gaps nucleotides during sequencing. The phylogenetic tree was constructed based on distance analysis using neighborjoining method. The construction of this phylogenetic tree used the MEGA 5 program. The trust values of each established branch were determined using bootstrap analysis based on 1000 times re-sampling.

Table 1. Antagonistic Isolates and Their Inhibition Zone

\begin{tabular}{|c|c|c|c|c|c|}
\hline Colony code & $\begin{array}{l}\text { Average } \\
\text { length of my- } \\
\text { celium radius } \\
(\mathrm{cm})\end{array}$ & $\begin{array}{c}\text { Inhibitory } \\
\text { zone (\%) }\end{array}$ & Colony code & $\begin{array}{l}\text { Average } \\
\text { length of my- } \\
\text { celium radius } \\
\text { (cm) }\end{array}$ & $\begin{array}{c}\text { Inhibitory } \\
\text { zone (\%) }\end{array}$ \\
\hline BKA4*(b) & 2,10 & 53,33 & & & \\
\hline BKA5(cd) & 2,73 & 39,26 & BKD2(efghij) & 3,13 & 30,37 \\
\hline BKA6(jkl) & 3,50 & 22,22 & BKA52*(b) & 2,10 & 53,33 \\
\hline BKA10*(a) & 1,73 & 61,48 & BKA53(ghijkl) & 3,33 & 25,93 \\
\hline BKA14(efghi) & 3,10 & 31,11 & BKA59(b) & 2,33 & 48,15 \\
\hline BKA15(kl) & 3,53 & 21,48 & $\mathrm{BKP} 2 *(\mathrm{~b})$ & 2,13 & 52,59 \\
\hline BKA23(b) & 2,27 & 49,63 & BKA60(cdefgh) & 3,03 & 32,59 \\
\hline BKA25(ijkl) & 3,47 & 22,96 & BKA61(defgh) & 3,07 & 31,85 \\
\hline BKA28(kl) & 3,53 & 21,48 & BKB12(ghijkl) & 3,33 & 25,93 \\
\hline BKA30(efghi) & 3,10 & 31,11 & BKB18(cdefg) & 2,97 & 34,07 \\
\hline BKA31(ijkl) & 3,47 & 22,96 & BKA69(fghijkl) & 3,27 & 27,41 \\
\hline BKA34(ijkl) & 3,43 & 23,70 & BKA72(m) & 3,90 & 13,33 \\
\hline BKA38(fghijkl) & 3,27 & 27,41 & BKA74(ghijkl) & 3,33 & 25,93 \\
\hline BKA39(hijkl) & 3,40 & 24,44 & BKA77(cde) & 2,90 & 35,56 \\
\hline BKA40(hijkl) & 3,40 & 24,44 & BKB26(cdefgh) & 3,03 & 32,59 \\
\hline BKA41(cdef) & 2,93 & 34,81 & BKA88(efghijk) & 3,17 & 29,63 \\
\hline BKA43*(b) & 2,13 & 52,59 & BKB20(b) & 2,33 & 48,15 \\
\hline BKB2(cdefg) & 2,97 & 34,07 & BKB22(b) & 2,30 & 48,89 \\
\hline BKA44(ijkl) & 3,47 & 22,96 & BKB29*(b) & 2,10 & 53,33 \\
\hline BKA45(lm) & 3,60 & 20,00 & BKB31(efghijk) & 3,17 & 29,63 \\
\hline BKA48(cdefgh) & 3,03 & 32,59 & BKB30(c) & 2,70 & 40,00 \\
\hline BKA50(ijkl) & 3,43 & 23,70 & BKB32(b) & 2,33 & 48,15 \\
\hline
\end{tabular}

Note: the value above is the percentage of inhibition zone compared with the negative control $(\mathrm{n}=3)$. Radius mycelium control is $4.5 \mathrm{~cm}$. The numbers followed by the same letter show no significant difference based on the Duncan test at a 95\% confidence interval. (*) Isolates with inhibition zone of more than $50 \%$ 


\section{Results and Disscussion}

A total of 126 colonies was determined by colony morphology and explant sources. 89 colonies were derived from roots, 33 colonies from fruit, 6 colonies from midrib, and 6 colonies from leaves. Anti-fungal activies of bacterial colonies were then assessed using dual culture method. ${ }^{19}$ The presence of inhibitory zones were observed in several isolates, with 35 colonies derived from roots (BKA), 6 colonies from fruit (BKB), 1 midrib colony (BKP) and 1 leaf colony (BKD) Figure 1). A total of 43 colonies who had an inhibitory zone hereinafter called antagonistic colony (Table 1).

The percentage of antagonistic colonies reached approximately $34 \%$ of all cultured colonies. The proportion and composition of indigenous endophytic bacteria (endophytes that naturally colonize plant roots) with their antagonistic capacity were influenced by variations in biotic and abiotic factors, with the plant itself being the primary factor. ${ }^{20}$ According to Hallman et al, there were plant-specific species factors such as root shape, surface structure, root exudate composition, as well as non-plant factors such as mycorization or injury that might affect the spectrum of bacteria to colonize. Endophytic bacteria could increase host resistance to pathogens by a process called induced systemic resistance (ISR) and the application of chemical compounds called systemic acquired resistance (SAR). ${ }^{21}$

The results showed that of these 43 antagonistic colonies, there were six isolates possessing inhibitory zones of more than 50\% i.e., BKA 4, BKA 10, BKA 43, BKA 52, BKP 2, and BKB 29 (Figure 2). These isolates were distinguished by the morphology of colonies and cell morphology. One isolate (BKA-10) had the largest inhibitory zone, with 3 repetitions, wiht the average of 61 . $48 \%$. It had significantly different value compared to the inhibition zone of the other isolate with 95\% confidence interval (Table 1). Isolate BKA 10 was then selected for further identification.

\section{Identification of selected bacterial isolates Morphological Identification}

The results of morfological identification showed that visually, the BKA colonies had irregular shapes, milky white collor, the edges of filamentous colonies, and smooth surfaces, with a colony diameter of about 2.5

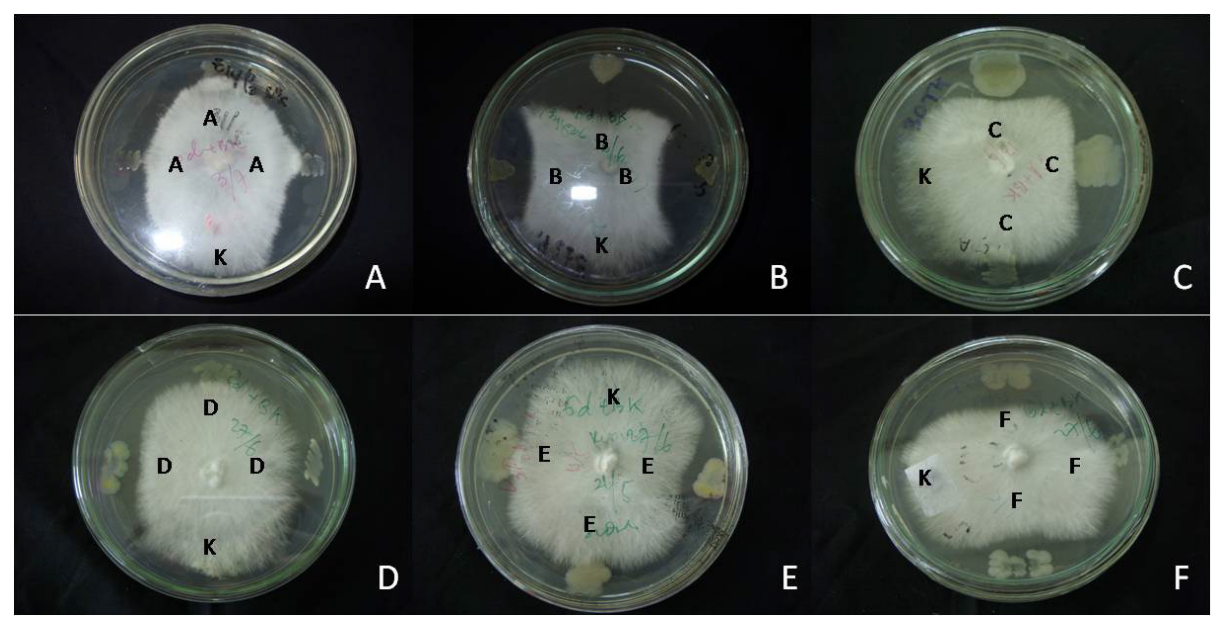

Figure 2. Antagonistic Test of Endophytic Bacteria with Dual Culture Method ( A) BKA 4, (B) BKA 10, (C) BKA 43, (D) BKA 52, (E) BKP 2, (F) BKB 29. (

*) K: Control, ZH: Inhibition Zone. 


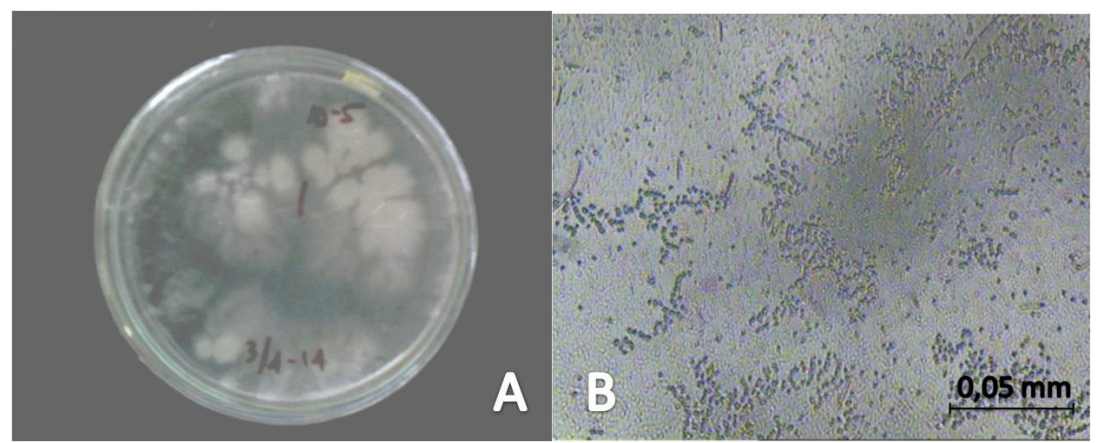

Figure 3. BKA 10 morfology (A) Colony shapes in NA culture, (B) Gram Staining Cell Form

$\mathrm{mm}$. Gram staining results showed that the isolates were a type of gram $(+)$ bacteria, It was a rod-shaped bacteria, with no slim when tested for $\mathrm{KOH}$ (Figure 3).

\section{Molecular Identification of $16 S$ rRNA}

Molecular identification was then performed on selected isolates, using primer 16S rRNA. The PCR results showed that the amplycons are at $1500 \mathrm{bp}$, parallel to the positive controllable amplicons (Fig. 4). Amplycon was then sequenced and aligned using BLASTn program.

\section{$16 S$ rRNA sequencing gen}

The successful sequence of amplionic has a length of $1472 \mathrm{bp}$ after the contig of the two-way nucleotide sequencing result using the Bioedit program. This sequence then was searched for reference species using the BLASTn program.

\section{Phylogenetic Tree Analysis}

The subject species database base that emerged from the analysis using the BLASTn program was used as material to construct phylogenetic trees using the Mega 5 program. The reference species search results for the BKA 10 (query sequence) using the BLASTn program showed that BKA 10 sequences had similarities to the Bacillus cereus group with a percentage of similarity of $100 \%$. The percentage of identity showed the number of identical nucleotide base residues at the alignment of two sequences. ${ }^{22}$ Pairwise pairing and multiple sequences were performed between BKA 10 sequences and some sequences of subjects derived from BLASTn results using the Mega 5 program. Bacillus myocoides is used as outgrup.

The result of phylogenetic tree construction with neighbourjoining test (Figure 5) showed

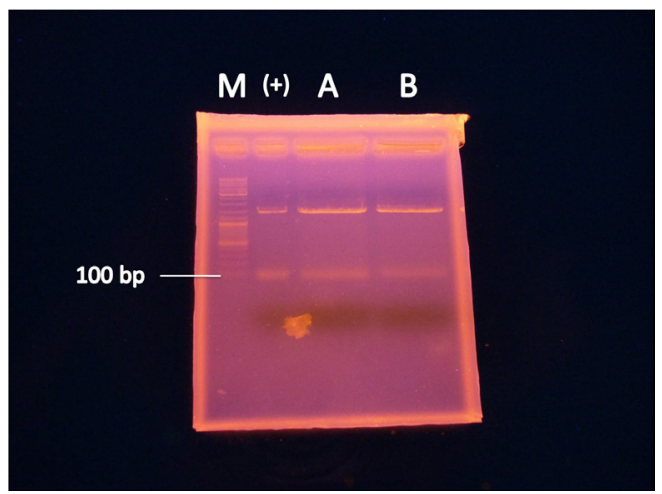

Figure 4. Amplicon PCR 16S rRNA BKA 10 isolates (A) \& (B) 


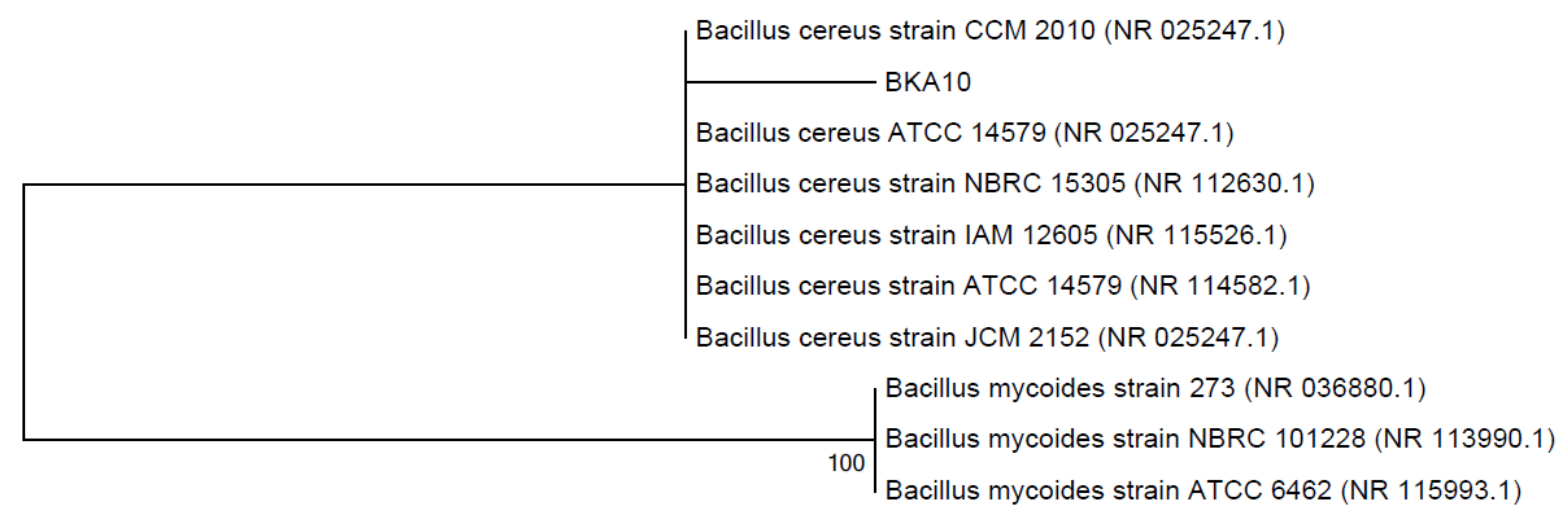

0.0005

Figure 5 Construction of Phylogenetic Tree Isolate BKA 10

that isolate BKA 10 belongs to Bacillus cereus group with a genetic distance of about 0.0006 with Bacillus cereus group. It is therefore suspected that the isolate BKA 10 has a close kinship with the Bacillus cereus species.

Bacillus cereus is a rod-shape, aerobicfacultativebacteria $(1 \times 3-4 m$ size $)$, which is belong to Gram-positive group. It forms endospore. Its cell structure contains an inner membrane and a thick peptidoglycan whose function is to treat the cell surface. ${ }^{23}$ Bacillus cereus is a mesophyll bacteria, that grows optimally at temperatures between $20^{\circ} \mathrm{C}-40^{\circ} \mathrm{C}$ and can adapt to a wide range of environmental conditions. These bacteria are widely distributed in nature and commonly found in soils as saprophytic organisms. ${ }^{24}$ Bacillus cereus also contributes to insect microflora, obtains nutrients from host, found in rhizosphere in a number of plants. ${ }^{24}$

Biocontrol agents are an alternative choice of chemical pesticides that can suppress plant pests and also increase plant growth. There are strains that produce HBL enterotoxins. This antifungal compound from Bacillus cereus strain has been developed as a biocontrol agent that is useful for suppressing fungi and agricultural crop diseases ${ }^{25}$.
The following is a classification of Bacillus cereus based on available data at http://www. ncbi.nlm.nih.gov/Taxonomy/Browser:

$\begin{array}{ll}\text { Domain } & : \text { Bacteria } \\ \text { Phylum } & \text { : Firmicutes } \\ \text { Class } & : \text { Bacilli } \\ \text { Order } & : \text { Bacillales } \\ \text { Family } & : \text { Bacillaceae } \\ \text { Genus } & : \text { Bacillus } \\ \text { Species Group } & : \text { Bacillus cereus group }\end{array}$

Bacillus cereus interacts with other microorganisms in the rhizosphere the region surrounding the plant. The benefit of the presence of Bacillus cereus in plant is its ability to inhibit pathogen-induced plant diseases and also the ability to increase plant growth $^{26}$. A research by Hakizimana et al showed that Bacillus cereus was the largest endophyte species in avocado root (35.7\%), and was the largest inhibitor $(28.4 \%)$ in the avocado pathogen fungi on avocado plants, among the other five endophytic species exhibiting antagonistic properties. ${ }^{27}$

\section{Conclusion}

Isolate with the bestanti-fungal acitviity against $G$. boninense mycelium has the closest kinship with Bacillus cereus. 


\section{Acknowledgements}

This research was supported by bandung Institute of Technology. Special appreciation is extended to Mr. I Nyoman P Aryantha for his guidance and technical support. We would like to thank staff of PAU and Molecular Lab for their support and assistant during research activities.

\section{Funding}

Financial support from PT. Agro Astra Lestari is gratefully appreciated.

\section{Conflict of Interest}

Not declared.

\section{Reference}

1. Ulum M \& Hariyanto. Indonesian oil Palm Statistic. Statistics-Indonesia. 2011 BPS catalogue: 5504003.

2. Wright RT, Wiyono IE. Indonesia Oilseeds and Product Annual. USDA Foreign Agricultural Service GAIN Report. 17 March 2014. Number:ID1405.

3. USDA. Oilseeds: World Market and Trade, USDA Foreign Agricultural Service. Circular Series. January 2010.

4. Chong KP. An evaluation of Ganoderma fungal colonisation using ergosterol analysis and quantification. The Planter. 2012;88(1034):311-319.

5. Ommelna BG, Jennifer AN, Chong KP. The potential of chitosan in suppresing Ganoderma boninense infection in oilpalm seedlings. Journal of Sustainable Science Management. 2012;7(2):186192.

6. Chung GF. Management of Ganoderma disease in oil palm plantations. The Planter. 2011; 87(1022), 325-339.

7. Hushiarian R, Yusof NA, Dutse SW. Detection and control of Ganoderma boninense: Strategies and perpectives. Springer Plus. 2013;2:55.

8. Bivi MR, Farhana MS, Khairulmazmi
A, Idris A. Control of Ganoderma : A causal agent of basal stem rot disease in oil palm with endophyte bacteria in vitro. International Journal of Agricultural Biology. 2010;12(6), 833-839.

9. Idris AS, Noor Haida S, Nur Rashyeda R. GanoEF1-A fungal biocontrol agent for Ganoderma in oil palm. $M P O B$ Information Series. 2010;June:1-3.

10. Naher L, Yusuf UM, Tan SG, Siddiquee $\mathrm{S}$, Islam $\mathrm{M}$. In vitro and in vivo biocontrol performance of Tricoderma harzianum Rifai on Ganoderma boninense Pat. related to pathogenicity on oil palm (Elais gueensis Jacq.). Journal of Pure and Apllied Microbiology. 2014;8(2): 973-978.

11. Kobayashi DY, Palumbo JD. Bacterial endophytes and their effects on plants and uses in agriculture in bacon CW, white JF (eds.). Microbial endophytes. Dekker. New York. 2000; 199-236.

12. Zaiton S, Sariah M, Zainal AMA. Isolation and characterization of microbial endophytes from oil palm roots: Implication as biological control agents against Ganoderma. The Planter. 2006; 82(966), 587-597.

13. Kloepper JW, Wei G, Tuzun S. Rhizosphere population dynamic and internal colonization of cucumber by plant growth-promoting rhizobacteria wich induce systemic resistance to Colletotrichum orbiculare. Biological Control of Plant Disease. Plenum Press. New York. 1992; 185-191.

14. Dorworth CE, Callan BE. Manipulation of endophytic fungi to promote their utility as vegetation biocontrol agents. Endophytic Fungi in Grasses and Woody Plants-Systematics. Ecology and Ecolution. APS Press. New York. 1996; 209-218.

15. Bills GF. Isolation and analysis of endophytic fungal communities from woody plants. In: Redlin SC and Carris 
LM. American Phytopathological Society Press. New York. 1996; 31-65.

16. Pan MJ, Rademan S, Kuner K. Hasting JW. Ultrastructural studies on colonization of banana tissues and fusarium oxysporum $f$. sp. Cubean race 4 by the endophytic bacterium Burkholderia cepacia. Journal of Phytopatology. 1997; 145, 479-489.

17. Clay K. Fungal endophytes infection and the population biology of grasses. Cambridge University Press. UK. 1998; 225-285.

18. Jinantana J, M Sariah. Potential for biological control of slerotium foot rot of chilli by Tricoderma spp. Tropical Agriculture Science. 1998;21:1-10.

19. Hallmann J, Berg G. Spectrum and population dynamics of bacterial root endophyte Vol 9. Berlin Heidenberg: Spinger-Verlag. 2006; 15-28.

20. Germida JJ, Siciliano SD, Freitas JR, Seib AM. Diversity of root-associated bacteria associated with field-grown canola (Brassica napus L.) and wheat (Tricicum aestivum L.). FEMS Microbiology and Ecology. 1998;26:43-50.

21. Kloepper JW, Ryu CM. Bacterial endophytes as elicitors of induced systematic resistance. Microbial Root Endophyte Vol 9. Berlin Heidenberg: Spinger-Verlag. 2006: 33-50.

22. Madden T. The BLAST Sequence analysis tool. 2013 March 15. In: The NCBI Handbook [Internet]. 2nd edition. Bethesda (MD): National Center for Biotechnology Information (US); 2013. Available from: https://www.ncbi.nlm. nih.gov/books/NBK153387/

23. Ticknor OL, Kolsto AB, Hill KK, Keim $\mathrm{P}$, Laker MT, Tonks M, et al. Fluorescent amplified fragment length polymorphism analysis of Norwegian Bacillus cereus and Bacillus thuringiensis Soil Isolates. Applied Environmental Microbiology. 2001; 67(10): 4863-4873.

24. Vilain S, Luo Y, Hildreth M, Brozel
V. Analysis of the life cycle of the soil saprophyte Bacillus cereus in liquid soil extract and in soil. Applied Environmental Microbiology. 2006; 72(7): 4970-4977.

25. Sunaina V, Ajay, S, Dureja, P. Bacterial metabolites from Bacillus cereus B4 responsible for potato plant growth. Journal of the Indian Potato Association. 2005 ;32(3-4):187-188.

26. Jensen GB, Hansen BM, Eilenberg J, and Mahillon J. The hidden lifestyles of Bacillus cereus and relatives. Environmental Microbiology. 2003; 5(8): 631-640.

27. HakizimanaJD, GryzenhoutM, Countinho TA, van den Berg N. Endophytic diversity in Percea americana trees and their ability to display biocontrol activity against Phytoptora cinnamomi, Proceedings of VII World Avocado Congress;, 2011 September 5-9; Cairns, Australia; 2011. http://www.worldavocadocongress2011. com. 